\title{
Eksistensi Dukun dalam Era Dokter Spesialis
}

\author{
Irfan Ardani \\ Pusat Humaniora, Kebijakan Kesehatan dan Pemberdayaan Masyarakat \\ Badan Litbang Kesehatan Kementerian Kesehatan, Jl. Indrapura No. 17 Surabaya 60176 Indonesia
}

Email: ardhani.irfan@gmail.com

\begin{abstract}
Abstrak
Metode pengobatan berkembang sesuai dengan perkembangan dunia pemikiran dan kebudayaan manusia. Masa awal metode pengobatan tradisional sangat dipengaruhi oleh kepercayaan terhadap dunia non material. Periode pengobatan modern mengeliminasi kepercayaan itu dan lebih menawarkan pemahaman tentang kesehatan yang bisa diterima logika. Metode pengobatan tradisional tidak sepenuhnya hilang di masa modern ini. Eksistensinya masih bisa ditemukan di tengah-tengah masyarakat kita. Penelitian ini bertujuan untuk mengetahui keberadaan fisik dan keberadaan fungsi dari pengobat tradisional (dukun) di masa modern sekarang. Metode yang digunakan adalah studi pustaka dari hasil penelitian yang pernah dilakukan sebelumnya dan menganalisisnya dengan teori eksistensi. Hasilnya, secara fisik dan fungsi, praktik-praktik pengobatan tradisional masih hidup di tengah-tengah masyarakat dan masih dipercaya oleh sebagian masyarakat penggunanya.
\end{abstract}

Kata kunci: dukun, eksistensi, modern.

\section{Pendahuluan}

Pengertian sehat menurut WHO adalah suatu keadaan yang sempurna baik fisik, mental dan sosial tidak hanya bebas dari penyakit atau kelemahan (WHO, 1947). Definisi kesehatan menurut UndangUndang nomor 36 tahun 2009 adalah "keadaan sehat, baik secara fisik, mental, spiritual maupun sosial yang memungkinkan setiap orang untuk hidup produktif secara sosial dan ekonomi” (UU No. 36 tahun 2009). Kesehatan mencakup sebagian besar aspek kehidupan manusia, mulai dari proses terbentuknya seseorang sampai dengan akhir kehidupannya. Kesehatan juga mencakup hal makro kosmos dan mikro kosmos. Makro kosmos meliputi keberadaan alam semesta, lingkungan sebagai tempat seseorang tinggal, ekosistem yang melibatkan manusia di dalamnya. Mikro kosmos meliputi manusia sebagai individu, interaksinya dengan di luar dirinya, termasuk interaksi dengan orang lain, dengan lingkungan fisik dan lingkungan sosialnya. Konsep ini yang mendasari metode pengobatan tradisional. Penyakit dianggap sebagai ketidak-seimbangan antara unsur-unsur makro dan mikro kosmos. Penyakit dipengaruhi oleh lingkungan baik fisik maupun metafisik.

Paradigma positivis dalam ilmu pengetahuan modern membuat batasan nyata antara dunia fisik dan metafisika. Definisi kebenaran berkaitan dengan bagaimana akal atau rasio bisa menerima suatu pernyataan dan bisa dibuktikan secara empiris. Paradigma positivis dalam dunia modern telah melahirkan ahli-ahli kesehatan spesialistik dan mereduksi praktik-praktik kesehatan mistis yang lebih bersifat holistik. Peran dan fungsi dukun 
penyembuh pada masa tradisional digantikan oleh dokter dan lembaga-lembaga kesehatan modern.

Fenomena menarik adalah di tengah-tengah hegemoni dunia kesehatan modern dengan semakin banyaknya lembaga-lembaga pelayanan kesehatan dan dokter spesialis, keberadaan praktik-praktik tradisional ternyata masih hidup di masyarakat. Masyarakat sebagai pasien pun masih sangat mempercayai metode pengobatan tradisional tersebut.

\section{Metode}

Tulisan ini mengkaji fenomena dukun dalam era pengobatan modern dengan sudut pandang teori eksistensi. Pokok utama eksistensi adalah manusia dan cara beradanya yang khas di tengah-tengah manusia dan makhluk lainnya (Snijders, 2004). Eksistensi terkait erat dengan kesadaran manusia bahwa dalam hidup di dunia ini manusia terhubung dengan manusia lain, manusia saling tergantung dengan manusia lain (Salam, 1988).

Pengumpulan data menggunakan studi pustaka. Data yang digunakan merupakan hasil penelitian terdahulu terkait tema pengobatan tradisional dan pengobatan alterrnatif, ditambah literatur-literatur yang sesuai dengan tema. Yang membedakan dengan penelitian sebelumnya adalah, tulisan ini lebih menekankan pada tema eksistensi, terkait keberadaan fisik dan keberadaan fungsi dari pengobat tradisional (dukun) di dalam peradaban pengobatan modern sekarang.

\section{Hasil dan Pembahasan}

\subsection{Teori eksistensi}

Kata eksistensi berasal dari kata $e k s$ (keluar) dan sistensi, yang diturunkan dari kata kerja sisto (berdiri, menempatkan). Kata eksistensi diartikan bahwa manusia berdiri sebagai diri sendiri dengan keluar dari dirinya. Manusia sadar bahwa dirinya ada (Hadiwijono, 2005: 148). Menurut Loren Bagus (1996: 183), eksistensi berasal dari kata existence yang berasal dari Bahasa Latin existere yang berarti muncul, ada, timbul, atau memiliki keberadaan aktual. Existere sendiri berasal dari kata ex yang berarti keluar dan sistere yang berarti tampil atau muncul.

Kamus Bahasa Indonesia mendefinifikan eksistensi sama dengan keberadaan (Pusat Bahasa, 2008). Eksistensi terkait dengan keberadaan fisik dan fungsi yang melekat dalam dirinya.

\subsection{Pemaknaan kesehatan dari tradisional ke modern}

Kebudayaan pramodern yang dimulai dari kebudayaan primitif sampai dengan masa sebelum Renaissance, di sebagian besar peradaban dunia dalam mengkaji kesehatan selalu melibatkan dunia non material, dunia roh dan dewa-dewa. Selama berabad-abad penyembuhan telah dilakukan oleh penyembuh (dalam peradaban Indonesia dikenal istilah dukun) dengan tuntunan kearifan tradisional yang melihat penyakit sebagai suatu kekacauan manusia secara utuh, yang tidak hanya melibatkan tubuh pasien melainkan juga pikirannya, gambaran dirinya, ketergantungannya pada lingkungan fisik dan sosial, serta hubungan antara manusia dengan kosmos (alam raya) dan dewa-dewa (Capra, 2004). Penyembuhan dilakukan melalui upacara ritual 
untuk mempengaruhi pikiran pasien, membebaskan rasa takutnya yang selalu menjadi komponen penting penyakit dan membantu pasien merangsang autoimun yang dimiliki dan ada di dalam tubuh pasien sendiri. Ritual penyembuhan ini melibatkan suatu hubungan yang kuat antara penyembuh dengan pasien, yang sering ditafsirkan sebagai kekuatan supranatural yang disalurkan ke tubuh pasien.

Pergeseran pemahaman dari konsep kesehatan yang bersifat supranatural diawali sekitar 400 tahun sebelum masehi di Yunani. Seorang dokter pada masanya yang bernama Hippocrates menjelaskan bahwa penyakit tidak disebabkan oleh iblis atau kekuatan-kekuatan supranatural, tetapi merupakan fenomena alami yang dapat dipelajari secara ilmiah dan dipengaruhi oleh prosedur-prosedur terapeutik dan juga pengaturan hidup seseorang secara bijaksana. Ilmu kedokteran dipraktikkan sebagai sebuah disiplin ilmiah, yang didasarkan atas ilmuilmu alam yang mencakup pencegahan penyakit, diagnosis dan terapi. Hippocrates tetap mempertahankan faktor pengaruh dari luar seperti lingkungan dan kebiasaan sosial manusia. Pengaruh lingkungan fisik maupun sosial dipandang sebagai dasar esensial seni seorang dokter (Capra, 2004).

Perubahan mendasar pada pemahaman kesehatan terjadi pada era modern yang diawali oleh masa Renaissance pada abad ke 14 di Italia. Penemuan-penemuan mesin industri dan pemikiran rasionalisme dalam dunia filsafat yang dimotori Descartes telah mengeliminasi pola pikir non rasional termasuk dalam kajian kesehatan. Penyembuhan tradisional tersisihkan oleh pengobatan kedokteran modern. Pengobatan modern adalah perbuatan atau cara yang dilakukan manusia dalam upaya penyembuhan, pencegahan dan pemulihan penyakit dengan menggunakan produk, alat dan perlengkapan yang canggih dan modern yang dipercaya memberikan suatu kemudahan, efisisensi dan efektivitas dalam mempermudah pengobatan (Alia, tanpa tahun).

Awal abad modern terjadi revolusi mendasar dalam pengertian kesehatan. Paradigma berpikir rasionalisme Descartes yang membedakan dan memisahkan antara tubuh manusia dengan jiwa manusia berpengaruh pada pemikiran kedokteran. Tubuh manusia dianggap sebagai sebuah mesin yang bisa dianalisis menurut bagian-bagiannya. Penyakit dianggap sebagai ketidakberfungsian mekanisme biologis, peran dokter adalah campur tangan secara fisik maupun kimia untuk membetulkan ketidakberfungsian tersebut (Capra, 2004). Ilmu kedokteran setelah masa Descartes, masih mendasarkan bahwa pengertian tubuh sebagai mesin, penyakit sebagai konsekuensi rusaknya mesin dan tugas dokter memperbaiki mesin itu.

Spesialisasi dalam ilmu kedokteran, yang semakin memusatkan pada bagian tubuh yang semakin kecil, ilmu kedokteran modern sering kehilangan pandangan tentang pasien sebagai manusia dan mereduksi kesehatan menjadi keberfungsian mekanis. Hal ini menjadi kelemahan dalam pola penyembuhan kedokteran modern.

Tradisi pengobatan di Indonesia secara langsung memang tidak mengalami pergeseran pemikiran seperti di dunia barat. Budaya kesehatan di Indonesia berawal dari budaya kesehatan tradisional suku-suku yang ada. Sama halnya yang terjadi di wilayah lain di dunia, pengobatan oleh 


\begin{tabular}{|c|c|c|c|c|c|c|c|c|c|c|c|c|}
\hline \multirow{2}{*}{ Propinsi } & \multicolumn{6}{|c|}{ Penolong persalinan pertama } & \multicolumn{6}{|c|}{ Penolong persalinan terakhir } \\
\hline & $\mathbf{a}$ & $\mathbf{b}$ & c & d & $\mathbf{e}$ & $\mathbf{f}$ & $\mathbf{a}$ & b & c & d & e & $\mathbf{f}$ \\
\hline Nusa Tenggara Timur & 4.1 & 36.5 & 1.2 & 46.2 & 11.5 & 0.5 & 3.7 & 38.2 & 1.3 & 43.4 & 12.4 & 0.9 \\
\hline Maluku & 2.6 & 39.9 & 0.7 & 56.0 & 0.6 & 0.2 & 2.8 & 40.0 & 0.9 & 51.9 & 3.7 & 0.6 \\
\hline Maluku Utara & 6.7 & 32.7 & 1.7 & 56.7 & 1.6 & 0.6 & 7.4 & 34.3 & 1.5 & 55.1 & 1.1 & 0.6 \\
\hline Papua Barat & 3.6 & 47.1 & 1.6 & 21.4 & 22.3 & 3.9 & 4.2 & 50.2 & 1.4 & 20.4 & 19.8 & 3.9 \\
\hline Papua & 10.3 & 35.3 & 2.0 & 12.7 & 35.2 & 4.5 & 9.2 & 36.8 & 3.8 & 14.1 & 31.0 & 5.1 \\
\hline \multicolumn{13}{|l|}{ Tipe Daerah } \\
\hline Perkotaan & 14.3 & 60.3 & 0.7 & 19.8 & 4.3 & 0.6 & 13.6 & 61.7 & 1.4 & 18.7 & 4.0 & 0.7 \\
\hline Perdesaan & 2.7 & 31.1 & 1.6 & 45.9 & 17.0 & 1.8 & 2.6 & 32.9 & 1.8 & 43.7 & 16.9 & 2.2 \\
\hline \multicolumn{7}{|l|}{ Keterangan: } & \multicolumn{6}{|c|}{$\begin{array}{ll}\text { d. } & \text { Dukun bersalin } \\
\text { e. } & \text { Famili/ Keluarga } \\
\text { f. } & \text { Lainnya }\end{array}$} \\
\hline
\end{tabular}

Tabel 1: Persentase Ibu Mempunyai Bayi menurut Penolong Persalinan dan Provinsi, Riskesdas 2007

suku bangsa di Indonesia juga dipengaruhi dan melibatkan kepercayaan terhadap dunia non material, dunia roh dan dewa-dewa. Penyakit sering kali dianggap sebagai gangguan dari makhluk dunia non material, sehingga cara penyembuhannya adalah dengan mengusir makhluk tersebut dari dalam tubuh pasien. Untuk tugas penyembuhan ini, seorang dukun dipercaya mampu berhubungan dengan dunia non material, dunia roh dan dewadewa untuk mengusir gangguan yang menyebabkan sakit dan meminta kesembuhan si pasien.

Pengobatan modern masuk ke Indonesia seiring dengan ekspansi Negara Barat ke negaranegara Timur. Kedokteran modern yang bersifat rasional mereduksi keberadaan dukun yang non rasional. Lembaga-lembaga kesehatan modern seperti dokter, rumah sakit, obat modern dan lainlain semakin berkembang. Pendidikan modern juga mengajarkan bahwa pengobatan modern adalah pengobatan yang terbaik. Peraturan dan kebijakan negara melegitimasi bahwa metode pengobatan yang diakui adalah pengobatan modern. Keberadaan dukun dan praktik pengobatan tradisional semakin tersisih.

\subsection{Eksistensi dukun di Indonesia}

Keberadaan dukun pengobat dan praktik pengobatan tradisional ternyata masih eksis di tengah pengobatan modern. Eksistensi mereka masih diakui oleh masyarakat sebagai penggunanya. Berbagai jenis dukun diantaranya, 1) dukun pijat yang bekerja untuk menyembuhkan penyakit yang 
disebabkan karena kurang berfungsinya urat-urat dan aliran darah, 2) dukun Sangkal Putung yang mengobati pasien patah tulang, 3) dukun Petungan yang memberi nasihat berupa perhitungan hari baik menurut Weton (kitab primbon), 4) dukun yang pandai mengobati gigitan ular berbisa dan binatang buas, 5) dukun bayi yaitu dukun yang memberikan pertolongan pada waktu dan setelah persalinan, dan 6) dukun Perewangan yaitu dukun yang dianggap memiliki kemamuan magis sehingga dapat memberikan pengobatan maupun nasihat yang berhubungan dengan alam gaib (Anggorodi, 2009).

Sebagai contoh eksistensi dukun dalam era pengobatan modern di Indonesia dapat kita lihat dari Hasil Riset Kesehatan Dasar tahun 2007 yang menunjukkan persentase yang tinggi dalam pemanfaatan dukun untuk menolong persalinan. Tabel di bawah ini menunjukkan lima provinsi dengan tingkat pemanfaatan tenaga dukun persalinan tertinggi di Indonesia. Maluku Utara yang menduduki posisi pertama menunjukkan sebanyak 56,7 \% persalinan anak pertama dan 55,1 $\%$ persalinan anak terakhirnya ditolong oleh dukun. Dari tabel di atas terlihat bahwa tingkat kepercayaan masyarakat terhadap dukun dalam menolong persalinan masih tinggi terutama di daerah pedesaan. Hal ini juga menunjukkan bahwa keberadaan dukun dan fungsinya sebagai pengobat masih melekat dalam keseharian masyarakat Indonesia.

Fenomena lain yang cukup mengejutkan adalah munculnya Ponari tahun 2009, dukun cilik dadakan asal Jombang Jawa Timur. Setiap hari ada sekitar lima puluh ribu kupon antrian berobat terjual. Pasiennya bukan hanya berasal dari
Jombang, tetapi juga dari luar kota. Metode pengobatan yang digunakan juga sangat sederhana, cukup dengan merendam batu dalam air. Penggunaan untuk obat pun diserahkan kepada masing-masing pasien, diminum maupun diusapkan pada tubuh yang sakit (Kuntari, tanpa tahun).

Pengobatan tradisional seperti Ponari dalam pandangan masyarakat awam merupakan metode pengobatan yang dapat menyembuhkan semua jenis penyakit. Berbeda dengan pengobatan modern yang semakin menuju kearah spesialisasi. Satu penyakit akan ditangani oleh dokter spesialis tertentu. Keunggulan pengobatan modern adalah sifat ilmiahnya yang dapat diterima logika. Sifat ilmiah yang dapat terukur dan dapat diuji akurasinya oleh ilmuan atau praktisi kesehatan lain. Dengan demikian, seorang dokter dapat saja dituduh melakukan malpraktik apabila ia melakukan pengobatan di luar bidang spesialisasinya.

Pengobatan tradisional oleh dukun merupakan tahapan-tahapan subjektif yang tidak dapat diukur. Ia tidak memiliki variabel yang jelas, dengan demikian ahli kesehatan lain tidak dapat mengukur kebenaran maupun kesalahan metode yang digunakan (Kuntari, tanpa tahun). Dukun pengobat memiliki wewenang kharismatis, yaitu kemampuan atau wibawa yang khusus terdapat di dalam dirinya. Wibawa ini dimiliki tanpa dipelajari, tetapi ada dengan sendirinya (Anggorodi, 2009). Sifat khas inilah yang menjadi modal sosial yang menarik keercayaan masyarakat untuk menggunakannya.

Eksistensi terkait erat dengan kesadaran manusia bahwa dalam hidup di dunia ini manusia terhubung dengan manusia lain, manusia saling tergantung dengan manusia lain (Salam, 1988). 
Eksistensi metode pengobatan tradisional dan eksistensi dukun sangat ditentukan oleh masyarakat sebagai penggunanya. Ia ada ketika masyarakat masih mempercayai dan menggunakannya. Dukun yang dominan bersifat irasional masih eksis di tengah masyarakat modern dengan pola pikir rasional.

\section{Simpulan}

Eksistensi dukun dan metode pengobatannya yang tradisional masih hidup di tengah era pengobatan modern sekarang ini. Ia ada karena masyarakat sebagai pengguna masih mempercayainya. Contoh nyata adalah fenomena dukun cilik Ponari yang mampu menarik kurang lebih 50.000 antrian pasien setiap hari.

Keunggulan pengobatan oleh dukun adalah sifat universalnya. Pengobatan tradisional dalam pandangan masyarakat awam merupakan metode pengobatan yang dapat menyembuhkan semua jenis penyakit. Berbeda dengan pengobatan modern yang semakin menuju kearah spesialisasi. Satu penyakit hanya akan ditangani oleh dokter spesialis tertentu.

\section{Daftar acuan}

Alia, Mirna Nur. Belian Sasak di Tengah Pengobatan

\section{Modern,}

http://sosiologi.upi.edu/artikelpdf/beliansasak .pdf, diakses pada 27 Desember 2012

Anggorodi, Rina. 2009, "Dukun Bayi Dalam

Persalinan Oleh Masyarakat Indonesia”,

Makara Kesehatan, vol 13, no. 1, Juni, pp.9-

14

Badan Penelitian dan Pengembangan Kesehatan.

2008. Laporan Nasional Riset Kesehatan
Dasar (RISKESDAS) 2007. Laporan penelitian, Badan Litbangkes Kementerian

Kesehatan

Bagus, Lorens. 1996. Kamus Filsafat. Jakarta: Gramedia

Capra, Fritjof. 2004. Titik Balik Peradaban. Yogyakarta: Penerbit Bentang

Hadiwijono, Harun. 2005. Sari Sejarah Filsafat Barat 2. Yogyakarta: Kanisius

Kuntari, Titik. Fenomena Pengobatan Alternatif di Tengah Mahalnya Pelayanan Jasa Kesehatan. Elearning Pendidikan Klinik State Ilmu Kesehatan Masyarakat IKM, Fakultas Kedokteran Universitas Islam Indonesia, http://medicine.uii.ac.id/upload/klinik/elearn ing/ikm/fenomena-pengobatan-alternatiffkuii-tk.pdf, diakses pada 27 Desember 2012

Pusat Bahasa. 2008. Kamus Bahasa Indonesia,

Jakarta: Pusat Bahasa Departemen

Pendidikan Nasional

Salam, Burhanuddin. 1988. Filsafat Manusia (Antropologi Metafisika. Jakarta:Bina Aksara Snijders, Adelbert. 2004. Antropologi Filsafat: Manusia, Paradoksdan Seruan. Yogyakarta: Kanisius

World Health Organization, WHO Definition of Health, http://www.who.int/about/definition/en/prin t.html, diakses pada 28 Desember 2012 